\title{
Meiotic maturation of mouse oocytes triggers the translation and polyadenylation of dormant tissue-type plasminogen activator mRNA
}

\author{
Joaquin Huarte, ${ }^{1}$ Dominique Belin, ${ }^{2}$ Anne Vassalli, ${ }^{1}$ Sidney Strickland, ${ }^{1,3}$ and Jean-Dominique \\ Vassalli $^{1}$ \\ ${ }^{1}$ Institute of Histology and Embryology and 2Department of Pathology, University of Geneva Medical School, 1211 Geneva 4, \\ Switzerland
}

\begin{abstract}
The serine protease tissue-type plasminogen activator $(\mathrm{t}-\mathrm{PA})$ is synthesized by murine oocytes undergoing meiotic maturation, but not by arrested primary oocytes. Dormant, stable t-PA mRNA accumulates during oocyte growth, so that fully grown, arrested primary oocytes contain in their cytoplasm approximately 10,000 copies of this molecule. Translation of t-PA mRNA is triggered upon resumption of meiosis and is accompanied by a progressive and concerted increase in its size. This structural change can be accounted for by increased polyadenylation at the $3^{\prime}$ end of the molecule. Following its translation, t-PA mRNA is degraded; it is no longer detectable in fertilized eggs. The identification of a dormant mRNA in murine oocytes and the demonstration that its translational activation is accompanied by elongation of its poly(A) tail may provide insights into the control of gene expression during meiotic maturation and early mammalian development.
\end{abstract}

[Key Words: Oogenesis; maternal mRNA; t-PA; translation]

Received September 14, 1987; accepted October 14, 1987. '

The meiotic maturation of oocytes and the initiation of embryonic development both involve the translational activation of preformed mRNA molecules. Indeed, during the growth phase of the oocyte there is synthesis and storage of a number of mRNA species that remain untranslated or dormant until specific developmental stages (for review see Davidson 1976; Bachvarova 1985). The timed expression of such "maternal" mRNAs is critical to the initiation of development, but the mechanisms of control that must be involved have not been elucidated. In a few instances, it has been shown that translational activation of dormant mRNAs is accompanied by elongation of their $3^{\prime}$ poly(A) tails (Colot and Rosbash 1982; Rosenthal et al. 1983; Dworkin and Dworkin-Rastl 1985; Rosenthal and Wilt 1986; Rosenthal and Ruderman 1987). In mammals, the evidence for maternal mRNAs relies mostly on the fact that RNA synthesis inhibitors do not affect the changes in protein synthesis that occur during meiotic maturation and immediately after fertilization (Braude et al. 1979); in addition, in vitro translation experiments have shown that oocytic mRNA can code for proteins that are not synthesized until after fertilization /Cascio and Wassarman

3Permanent address: Department of Pharmacology, State University of New York, Stony Brook, New York 11794 USA.
1982). However, no specific untranslated mRNA has yet been identified in mammalian oocytes.

We have previously shown that ovulated mouse secondary oocytes contain tissue-type plasminogen activator $(t-P A)$, whereas primary oocytes do not. During spontaneous meiotic maturation in vitro, $t$-PA becomes detectable $5 \mathrm{hr}$ after germinal vesicle breakdown (GVBD); enzyme content then increases progressively to reach a plateau $9 \mathrm{hr}$ after GVBD. Accumulation of $\mathrm{t}-\mathrm{PA}$ requires meiotic maturation, since primary oocytes cultured under conditions that prevent resumption of meiosis do not contain the enzyme (Huarte et al. 1985). Oocyte RNA synthesis is essentially absent after GVBD (Bachvarova 1985), and inhibitors of RNA synthesis do not affect accumulation of $t$-PA during maturation; in contrast, culture in presence of protein synthesis inhibitors completely prevents enzyme production (Huarte et al. 1985). Taken together, these results suggest the presence of dormant $\mathrm{t}$-PA mRNA in primary oocytes and its translational activation following GVBD.

In the present work, we document the accumulation of t-PA mRNA in growing oocytes and its translation and subsequent degradation during meiotic maturation. Furthermore, we have found that translation of $t-P A$ mRNA is accompanied by a change in its primary structure. 


\section{Results}

t-PA is synthesized by oocytes undergoing meiotic maturation, but not by arrested primary oocytes

Previous results indicated that secondary oocytes express t-PA activity, whereas primary oocytes do not (Huarte et al. 1985). One possible explanation of these results was that primary oocytes contain an inactive form of the enzyme that is activated upon meiotic maturation. To investigate this possibility, primary oocytes were cultured for $16 \mathrm{hr}$ in the presence of $\left[{ }^{35} \mathrm{~S}\right]$ cysteine under conditions that allow or prevent resumption of meiosis. Oocyte extracts were then immunoprecipitated with anti-t-PA antibodies. SDS-PAGE and autoradiography revealed in the immune precipitate of maturing oocytes a single newly synthesized polypeptide of apparent $M_{\mathrm{r}} 72 \mathrm{kD}$ (Fig. 1, lane A2), the size expected for single chain murine t-PA (Marotti et al. 1982). In contrast, no labeled protein was observed in the immune precipitate of nonmaturing primary oocytes (lane Al) or in a control immunoprecipitation of maturing oocytes with irrelevant antibodies (lane A3).

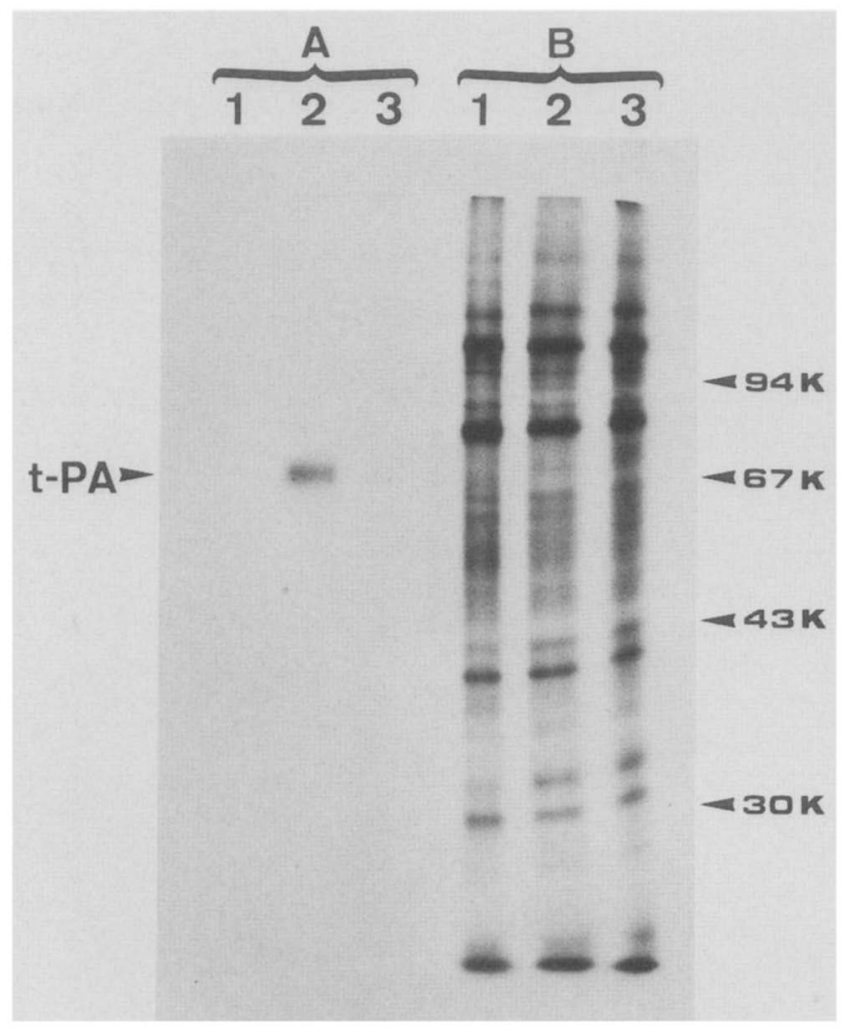

Figure 1. Determination of t-PA synthesis in arrested and maturing mouse oocytes. Primary oocytes were labeled with $\left[{ }^{35} \mathrm{~S}\right]$ cysteine, and lysates were analyzed by immunoprecipitation, SDS-PAGE, and autoradiography. $(A)$ Eluates of the S. aureusbound immune complexes; $(B)$ supernatants. (Lanes 1 ) Oocytes prevented from maturing by the presence of $\mathrm{Bt}_{2}$-cAMP (100 $\mu \mathrm{g} / \mathrm{ml}$ ) in the culture medium; immunoprecipitation with antit-PA IgG. (Lanes 2) Maturing oocytes; immunoprecipitation with anti-t-PA IgG. (Lanes 3) Maturing oocytes; immunoprecipitation with irrelevant IgG. The $M_{\mathrm{r}}$ values of standard proteins are shown.
Analysis of the supernatants from the immunoprecipitations (Fig. 1B) revealed few differences between the overall pattern of protein synthesis in arrested primary oocytes and in maturing oocytes. However, one difference was the presence of a $72-\mathrm{kD}$ band in the control supernatant from maturing oocytes (lane B3); this polypeptide, which was absent after immunoprecipitation with anti-t-PA antibodies (lane B2), is probably t-PA.

These results show that $\mathrm{t}-\mathrm{PA}$ is not detectably synthesized in meiotically arrested primary oocytes and that one conspicuous biosynthetic change that occurs during meiotic maturation is the induction of $\mathrm{t}$-PA synthesis. Thus, appearance of active enzyme after GVBD (Huarte et al. 1985) does not result from activation of a precursor form of the enzyme, but is a consequence of de novo synthesis of $\mathrm{t}-\mathrm{PA}$ protein.

\section{t-PA mRNA is present in the cytoplasm of primary oocytes}

Since the accumulation of t-PA activity during oocyte maturation also occurs in the presence of inhibitors of mRNA synthesis (Huarte et al. 1985), it was likely that t-PA synthesis results from translational activation of a pre-existing mRNA. Therefore, total RNA from primary oocytes was analyzed by Northern blot hybridization with a murine t-PA cRNA probe. Figure 2 shows that a single approximately 22S RNA species was revealed (lane a1), which could be detected in samples prepared from individual primary oocytes (lanes a2-4). This mRNA was detected in extracts of primary oocytes analyzed with two different mouse t-PA cRNA probes (Fig. $2 \mathrm{a}, \mathrm{b}$ ), as well as with a human t-PA cRNA probe (Fig. $5 \mathrm{cl}$, each of which is complementary to a different nonoverlapping region of $t-P A$ mRNA. By counting the amount of hybridized t-PA cRNA, we estimate that each oocyte contains approximately 10,000 molecules of t-PA mRNA.

To determine the localization of t-PA mRNA in primary oocytes, cytoplasms (Fig. 2e) and intact germinal vesicles (Fig. 2d) were isolated from mechanically broken oocytes. The samples were then processed for Northern analysis as described for whole oocytes. By comparison with a standard curve established using increasing numbers of oocytes per lane (not shown), we determined that at least $90 \%$ of $\mathrm{t}$-PA mRNA is stored in the cytoplasm of primary oocytes (Fig. 2B).

These results demonstrate that primary oocytes, which do not synthesize t-PA, contain high levels of a $\mathrm{t}$-PA mRNA species in their cytoplasm.

\section{t-PA mRNA accumulates during the oocyte growth phase}

Shortly after birth, a relatively synchronous wave of oocyte growth occurs in murine ovaries (Schultz and Wassarman 1977; Wassarman 1983). To determine the time at which t-PA mRNA appears, oocytes at successive stages of growth were obtained from females between 3 


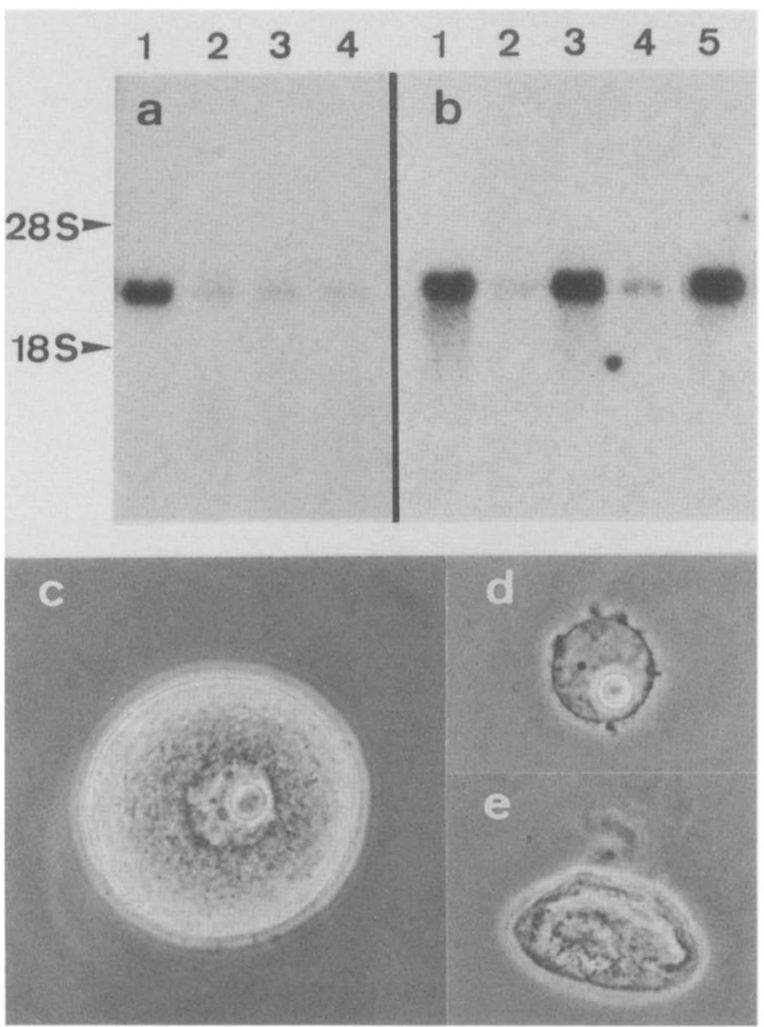

Figure 2. Detection and localization of t-PA mRNA in primary oocytes. (a) Northern blot analysis of RNAs prepared from 10 primary oocytes (lane 1) and from individual primary oocytes (lanes 2-4); the cRNA probe used was transcribed from pSP64-MT . (b) Northern blot analysis of RNAs prepared from 26 cytoplasms (lanes 1 and 3), 26 germinal vesicles (lanes 2 and 4 ), and 26 intact primary oocytes (lane 5); cRNA probe transcribed from pSP65-MT $\mathrm{M}_{1}$. RNAs electrophoresed in adjacent lanes were stained with ethidium bromide to determine the position of $18 \mathrm{~S}$ and $28 \mathrm{~S}$ rRNAs. $(c-e)$ Fractionation of primary oocytes: oocyte after removal of the zona pellucida $(c)$; isolated germinal vesicle $(d)$; broken, partially dispersed cytoplasm $(e)$.

and 18 days of age and their total RNA analyzed by Northern blot hybridization. No t-PA mRNA was observed in RNA prepared from a pool of 500 primordial oocytes (15 $\mu \mathrm{m}$ in diameter; not shown). t-PA mRNA was first detected in oocytes of $40-\mu \mathrm{m}$ diameter, and the bulk of t-PA mRNA was found to accumulate between the 40- and 50- $\mu \mathrm{m}$ stages (Fig. 3, lanes 1-3).

The steady-state level of t-PA mRNA remains nearly constant throughout the later phase of oogenesis (Fig. 3, lanes 3-6). This fact could be due to balanced rates of transcription and degradation or to stability of the mRNA without transcription. To discriminate between these possibilities, fully grown primary oocytes were cultured for $20 \mathrm{hr}$ under conditions that prevent resumption of meiosis and in the presence of actinomycin $\mathrm{D}$ to block synthesis of new mRNA molecules. The amount of t-PA mRNA in these cultured oocytes was nearly identical to that in primary oocytes lysed immediately after removal from the ovary or cultured in the absence of actinomycin D (Fig. 4). Since t-PA mRNA is

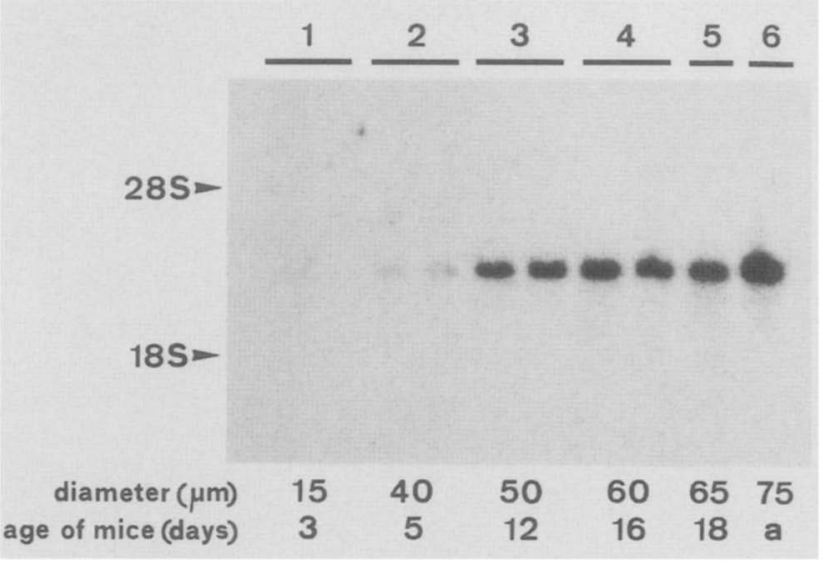

Figure 3. Accumulation of $t$-PA mRNA during oocyte growth. RNA from primordial, growing, and fully grown primary oocytes was analyzed by Northern blot hybridization using a cRNA probe transcribed from pSP65-MT . Each lane contains the RNA from 40 oocytes of the indicated size, derived from mice of the indicated age; $(a)=$ adult.

not degraded under these conditions, the maintenance of a stable steady-state level in fully grown oocytes does not appear to involve ongoing transcription of the gene.

No active t-PA enzyme could be detected in primary oocytes at different stages of growth (data not shown). Taken together with those of Figure 1, these results indicate that $t-P A$ gene transcription and t-PA mRNA accumulation occur at an early stage during the growth phase of oogenesis and that $\mathrm{t}$-PA mRNA remains stable and untranslated during the rest of the oocyte growth period, until shortly before ovulation, when meiosis resumes.

t-PA mRNA in secondary oocytes is less abundant and of larger apparent size than that in primary oocytes

Total RNA was prepared from an equal number of primary oocytes, ovulated secondary oocytes, and fertilized

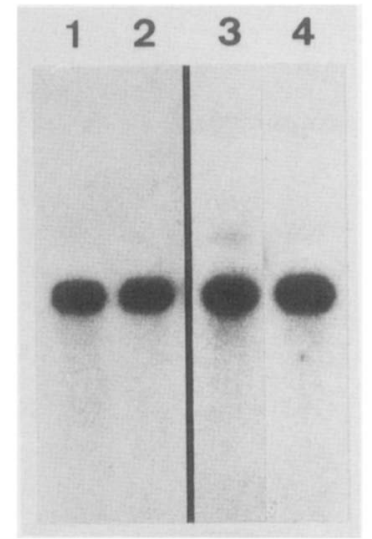

Figure 4. Stability of $t-P A$ mRNA in primary oocytes. RNA prepared from freshly isolated, fully grown primary oocytes (lanes 1 and 3) and from primary oocytes cultured in the presence of $\mathrm{Bt}_{2}$-cAMP $(100 \mu \mathrm{g} / \mathrm{ml})$ (lane 2) or in the presence of actinomycin $\mathrm{D}(5 \mu \mathrm{g} / \mathrm{ml})$ and $\mathrm{Bt}_{2}$-cAMP $(100 \mu \mathrm{g} / \mathrm{ml})$ (lane 4) was analyzed by Northern blot using a cRNA probe transcribed from pSP65-MT $\mathrm{M}_{1}$. Each lane contains the RNA from 20 oocytes. 
eggs and analyzed by Northern blot hybridization (Fig. 5). In both primary and secondary oocytes, a single RNA species was detected (lanes al and a2). However, both the intensity and the position of the respective bands were different: The hybridizing species in RNA from secondary oocytes (lane a2) appeared less abundant and of larger size than that in primary oocyte RNA (lane al). This difference in size was not due to a migration artifact since the two RNA species could be resolved after electrophoresis of a mixture of RNA from primary and secondary oocytes (lane a4). Finally, no signal was detected in RNA from fertilized eggs (lane a3).

Although the hybridizations were performed using stringent conditions under which the observed signals should reflect only authentic t-PA mRNA, it was important to verify this assumption given the different size of the mRNAs in primary and secondary oocytes. Therefore, two identical blots were probed in parallel, one with a mouse t-PA cRNA (Fig. 5b) and the other with a nonoverlapping human t-PA cRNA (Fig. 5c). Hybridization of these two probes to RNAs prepared from a t-PAproducing murine cell line (PYS; Fig. 5b,c, lanes 1; Marotti et al. 1982), primary oocytes (lanes 3), ovulated secondary oocytes (lanes 4), and in vitro-matured secondary oocytes (lanes 5) was compared. For all samples, equivalent signals were obtained with both probes. These results confirm that t-PA mRNA is responsible for the observed signals in both primary and secondary oocytes and that the level of t-PA mRNA is diminished following completion of the first meiotic division. They also demonstrate that t-PA mRNA in secondary oocytes is structurally different from that in primary oocytes.

\section{A progressive change in the structure of t-PA $m R N A$ occurs during meiotic maturation}

The difference in the sizes of primary and secondary oocyte t-PA mRNAs is not limited to in vivo-matured and ovulated cells. Indeed, a qualitatively similar difference was observed with oocytes that had undergone meiotic maturation in vitro (Fig. 5, lanes 5). Oocytes cultured for the same length of time in the presence of $\mathrm{Bt}_{2}-\mathrm{cAMP}$, to prevent resumption of meiosis, contained $t-P A$ mRNA of similar size to that in freshly prepared primary oocytes (Fig. 4, lane 2); thus, the change in size of this mRNA is related to progression of the cells through meiosis.

The change in the apparent size of t-PA mRNA could be due to transcription of new, larger mRNA molecules with concomitant degradation of the pre-existing species or to a modification of the structure of pre-existing mRNA. To distinguish between these possibilities, primary oocytes were allowed to mature in the presence of $\alpha$-amanitin or actinomycin $D$. The change in size of t-PA mRNA was not prevented by inhibition of transcription (Fig. 6) and must therefore result from a modification of the t-PA mRNA molecules present in primary oocytes. Furthermore, this modification does not appear to require the ongoing transcription of other genes.

The kinetics of this modification was analyzed by collecting cultured oocytes at different times during meiotic maturation. The increase in the size of $t-P A$ mRNA was progressive: it could be detected at $3 \mathrm{hr}$ after GVBD (see below, Fig. 8, lane 2) and was maximal at 16 hr (Fig. 7, lane 5). Interestingly, when the oocytes were collected at controlled times after GVBD, the apparent heterogeneity of $\mathrm{t}$-PA mRNA molecules /i.e., the width of the hybridizing band) did not change appreciably throughout meiotic maturation; thus, the change in size appears to occur synchronously and progressively for all $\mathrm{t}$-PA mRNA molecules.

A progressive decrease in the concentration of $t$-PA mRNA was detected starting at $12 \mathrm{hr}$ after GVBD (not shown); the t-PA mRNA content per oocyte was reduced by approximately $80 \%$ at $21 \mathrm{hr}$ post-GVBD (Fig. 7, compare lanes 6 and 8|. The decay of t-PA mRNA during the late phase of meiotic maturation is in accord with its absence in fertilized eggs (Fig. 5, lane a3).

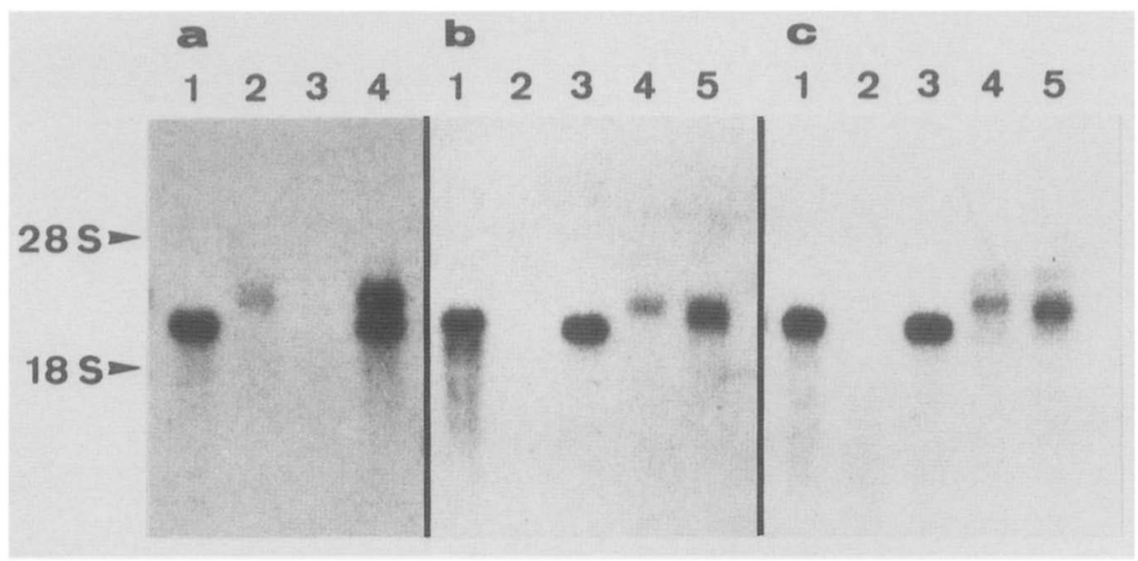

Figure 5. Northern blot analysis of t-PA mRNA in mouse oocytes and fertilized eggs. Panel $a$ was probed with a cRNA transcribed from pSP65-MT $\mathrm{MT}_{1}$ (lane 1) 40 primary oocytes; (lane 2) 40 ovulated secondary oocytes; (lane 3) 40 one-cell embryos (10 hr postfertilization); (lane 4) mixture of 20 primary oocytes and 60 ovulated secondary oocytes. Panel $b$ was probed with a murine t-PA cRNA (transcribed from pSP65-MT $\mathrm{MT}_{1}$ and panel $(c)$ with a human t-PA cRNA (transcribed from pSP65-MT ) $_{1}$; (lanes 1) total RNA from PYS cells $(4 \mu \mathrm{g}$ ); (lanes 2) E. coli carrier RNA alone; (lanes 3) 40 primary oocytes; (lanes 4) 39 ovulated secondary oocytes; (lanes 5) 48 secondary oocytes matured in vitro. 


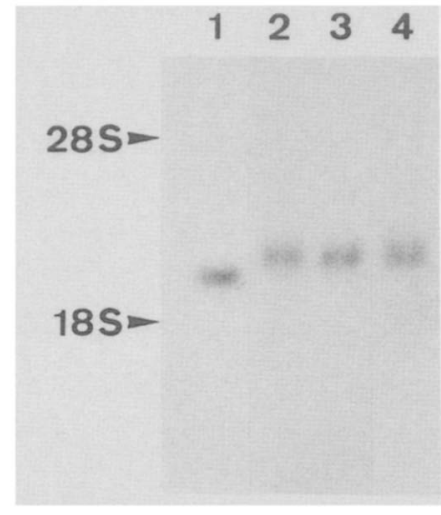

Figure 6. Effect of RNA synthesis inhibitors on the fate of t-PA mRNA during meiotic maturation. Freshly isolated primary oocytes (20 per group) were lysed immediately (lane 1 ), or after overnight culture in the presence of $\alpha$-amanitin $(11 \mu \mathrm{g} / \mathrm{ml})$ (lane 2), actinomycin D (5 $\mathrm{gg} / \mathrm{ml})$ (lane 3), or in the absence of drugs (lane 4). RNA was analyzed by Northern blot hybridization, using a cRNA probe transcribed from pSP65-MT $\mathrm{M}_{1}$.

Inhibition of protein synthesis is known to prevent meiotic progression at a stage shortly after GVBD (Wassarman et al. 1979). The presence of cycloheximide (Fig. 8, lane 3), puromycin (lane 5), or pactamycin (not shown) from the onset of the cultures prevented the increase in $\mathrm{t}$-PA mRNA size. Thus, the mixing of cytoplasm and nucleoplasm that occurs at GVBD is not sufficient to trigger the subsequent change in t-PA mRNA structure. Interestingly, when the antibiotics were added at $3 \mathrm{hr}$ after GVBD, the extent of the subsequent t-PA mRNA size increase was close to that in control cultures (Fig. 8, compare lanes 4 and 6 to lane 7). Hence, a critical biosynthetic event takes place around GVBD. Moreover, although the structural modification of $\mathrm{t}$-PA mRNA has only been initiated at $3 \mathrm{hr}$ post-GVBD (Fig. 8, lane 2), further protein synthesis, including translation of $\mathrm{t}-\mathrm{PA}$ mRNA, is not required for its progression.

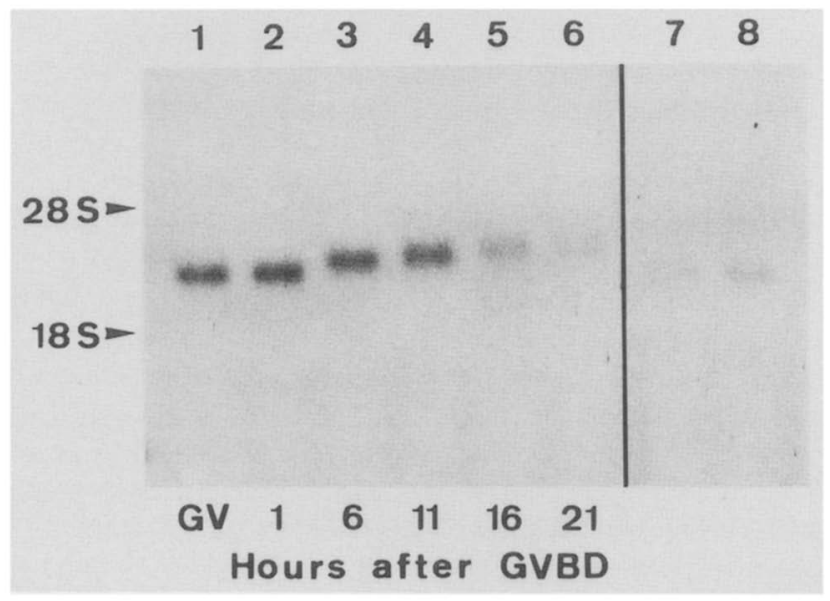

Figure 7. Northern blot analysis of t-PA mRNA at successive stages of meiotic maturation. Lanes 1-6 contain the RNA extracted from 20 oocytes. (Lane 1) Freshly isolated primary oocytes; (lanes 2-6) maturing oocytes (time is expressed as hours elapsed since GVBD); (lane 7) three primary oocytes; (lane 81 five primary oocytes. Probe used was transcribed from pSP65$\mathrm{MT}_{1}$.
The structural modification of $t-P A$ mRNA results from the elongation of a short poly(A) tail

To characterize the structural change in t-PA mRNA that occurs during meiotic maturation, total RNA from primary oocytes and ovulated secondary oocytes was exposed to proteinase $\mathrm{K}$ or to $\mathrm{RNase} \mathrm{H}$ in the presence of oligo(dT); RNase $\mathrm{H}$ degrades RNA in RNA-DNA hybrids and, in the presence of oligo(dT), will selectively remove poly(A) stretches in mRNAs (Vournakis et al. 1975). Proteinase K digestion did not affect the electrophoretic mobility of $t$-PA mRNA from either source. In contrast, RNase $\mathrm{H}$ treatment resulted in a marked decrease in the apparent size of secondary oocyte t-PA mRNA, but did not detectably change the migration of primary oocyte mRNA, so that RNase $\mathrm{H}$-treated $\mathrm{t}-\mathrm{PA}$ mRNAs from both types of oocytes were found to comigrate (not shown). Thus, the two t-PA mRNAs could differ only by the extent of their polyadenylation.

To refine this analysis, t-PA mRNA was cleaved into two fragments by performing the RNase $\mathrm{H}$ digestions in the presence of a synthetic oligonucleotide complementary to an internal segment of the mRNA (Fig. 9). After electrophoresis of the digestion products and Northern blot transfer, the filter was first hybridized to a t-PA $3^{\prime}$ probe. From the sequence of the cDNA, the $3^{\prime}$ fragment of t-PA mRNA, excluding the poly(A) tail, is 805 nucleotides long. In primary oocytes $(\mathrm{GV})$, ovulated secondary

\section{$\begin{array}{lllllll}1 & 2 & 3 & 4 & 5 & 6 & 7\end{array}$}

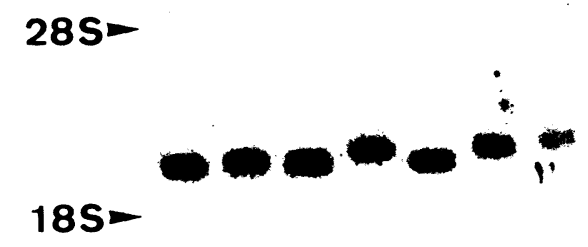

Figure 8. Effect of inhibitors of protein synthesis on the fate of t-PA mRNA during an overnight culture of primary oocytes. At the end of culture, oocytes were scored for their stage of maturation and lysed. [Abbreviations: (GV) Primary oocytes showing an intact germinal vesicle; (GVBD) oocytes without visible germinal vesicle, but no apparent polar body; $\left(\mathrm{O}_{\text {II }}\right)$ secondary oocytes (polar body present).] (Lane 1) Freshly isolated primary oocytes $(20 \mathrm{GV})$; (lane 2) primary oocytes cultured without drugs and lysed $3 \mathrm{hr}$ after GVBD (20 GVBD); (lane 3) incubation in the presence of cycloheximide $(10 \mu \mathrm{g} / \mathrm{ml})$ from the beginning of culture (20 GVBD); (lane 4) incubation in the presence of cycloheximide $(10 \mu \mathrm{g} / \mathrm{ml})$ from $3 \mathrm{hr}$ after GVBD (14 $\mathrm{O}_{\mathrm{II}}+6 \mathrm{GVBD}$ ); (lane 5) incubation in the presence of puromycin $(10 \mu \mathrm{g} / \mathrm{ml})$ from the beginning of culture (16 GVBD); (lane 6) incubation in the presence of puromycin $(10 \mu \mathrm{g} / \mathrm{ml})$ from $3 \mathrm{hr}$ after GVBD $\left(9 \mathrm{O}_{\mathrm{II}}+11 \mathrm{GVBD}\right)$; (lane 7) control oocytes after an overnight incubation without drugs $\left(13 \mathrm{O}_{\text {II }}+7\right.$ GVBD). Probe used was transcribed from pSP65-MT ${ }_{1}$. 
Figure 9. Northern blot analysis of RNase $\mathrm{H}$-treated $\mathrm{t}$-PA mRNA. Total RNA from 30 primary oocytes $(\mathrm{GV}), 125$ ovulated secondary oocytes $(\mathrm{OV})$, and from the t-PA-producing somatic cell line PYS $(10 \mu \mathrm{g})$ was hybridized to a 24-mer oligonucleotide complementary to $\mathrm{t}$-PA mRNA at positions 1680-1703, alone $(-)$ or together with oligo-d $(T)_{12-18}(+)$. After RNase $\mathrm{H}$ digestion, the RNAs were subjected to Northern blot analysis. The filter was first hybridized to a $3^{\prime}$ probe transcribed from pSP65- $\mathrm{MT}_{3}$ $(B)$. After elution of the probe, the filter was then hybridized to a $5^{\prime}$ probe transcribed from pSP65-MT $\mathrm{MT}_{1}(A)$; remaining traces of the $3^{\prime}$ probe are still visible in $A$. The position and size of marker RNAs electrophoresed and blotted in parallel are indicated. (C) Schematic diagram of t-PA mRNA showing the position of the oligonucelotides (not drawn to scale) and the two probes. Note that the 24-mer (positions 1680-1703) can also hybridize to 9 nucleotides at positions $1202-1210$.

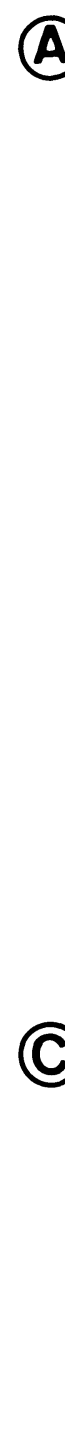

(A)
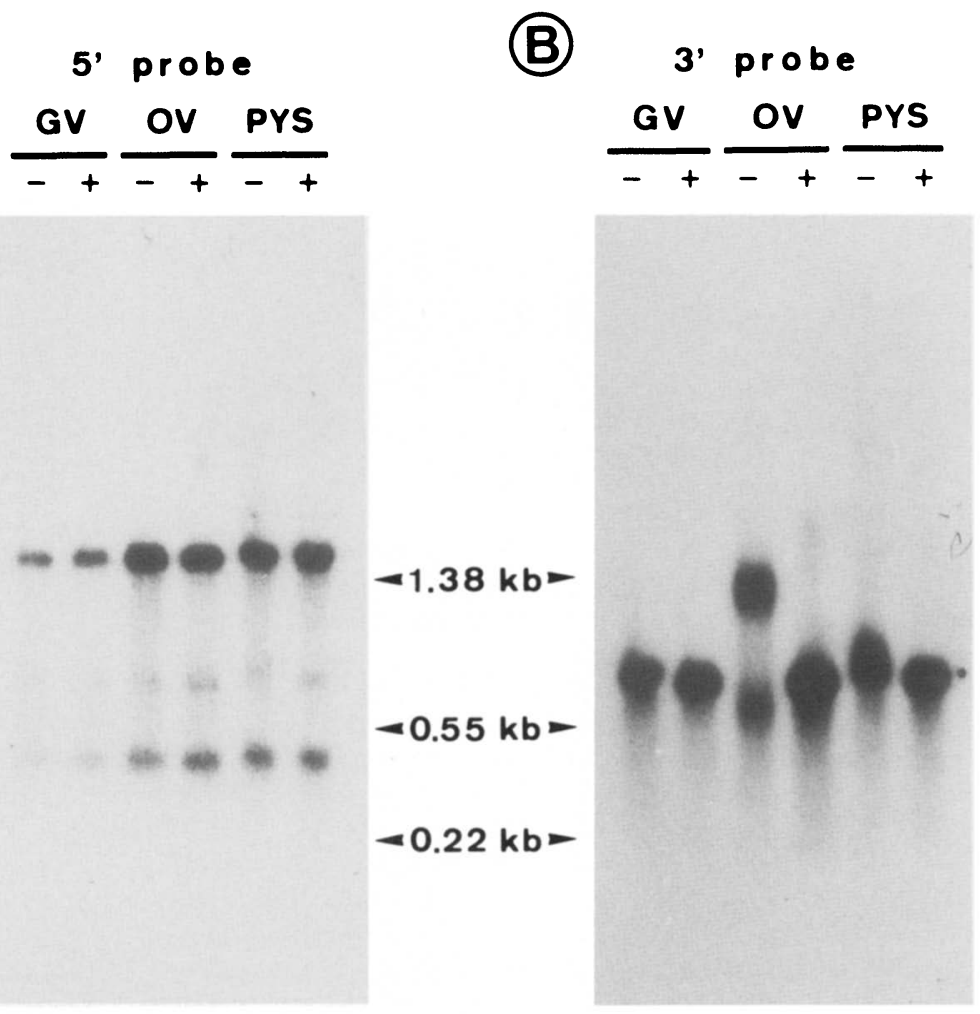

(C)
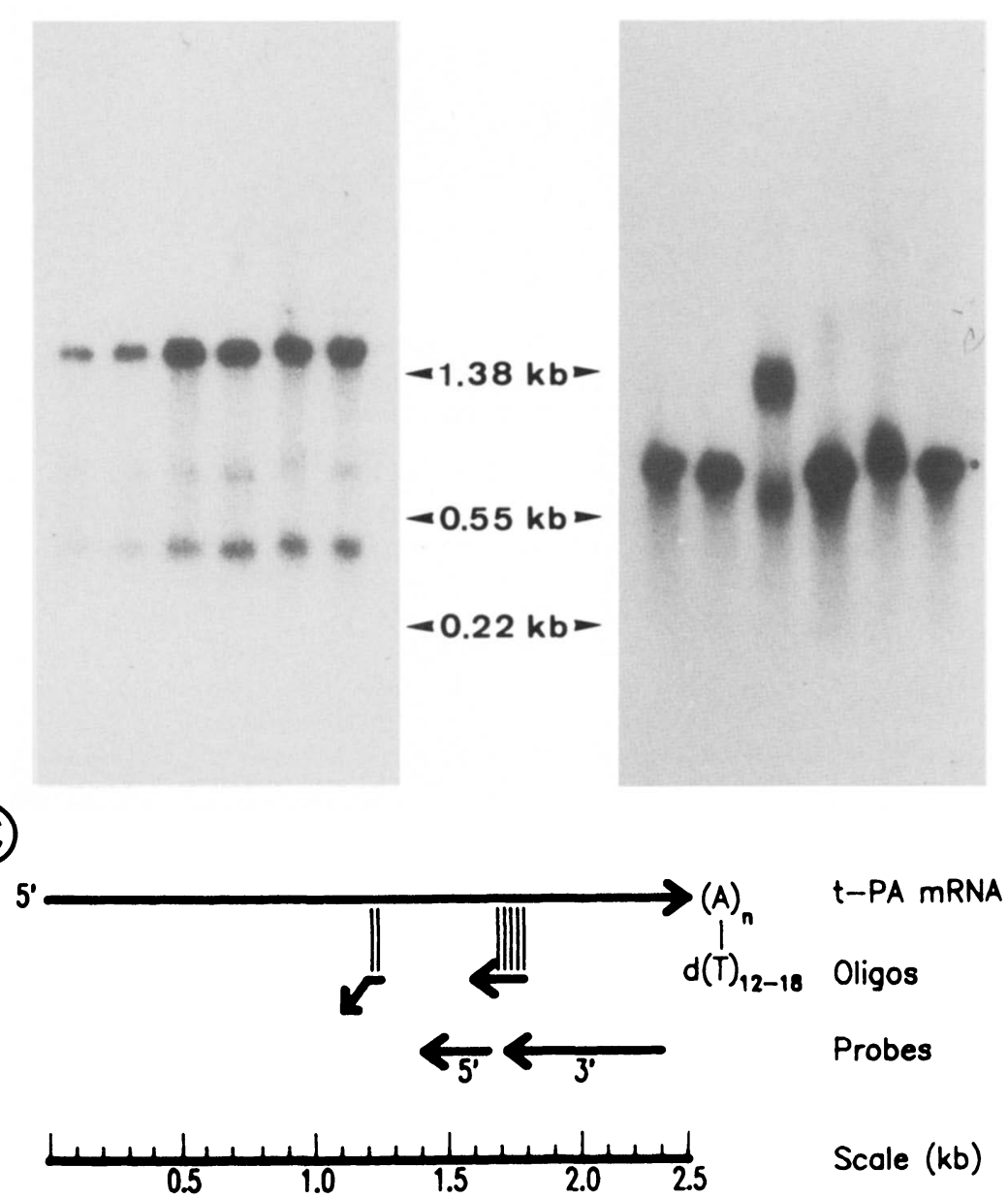

oocytes (OV), and somatic cells (PYS), the size of the major $3^{\prime}$ fragment was about $820,1200-1400$, and 800-950 nucleotides, respectively; an additional t-PA mRNA fragment of approximately 650 nucleotides was detected in the sample from secondary oocytes (se below). After digestion in the presence of oligo(dT), the $3^{\prime}$ fragments from all three sources comigrated and had the expected size of about 800 nucleotides. The probe was eluted, and the filter was rehybridized with a t-PA $5^{\prime}$ probe. In all samples, the major 5 ' fragment had the expected length of about 1700 nucleotides. A minor 500nucleotide band was also detected in all samples; this results from oligonucleotide-directed cleavage at a second upstream site, due to the presence of a 9-nucleotide complementary sequence (Fig. 9C). Taken together, these data show that (1) the size increase of t-PA mRNA during meiotic maturation corresponds to the addition of 400-600 nucleotides at the $3^{\prime}$ end of the molecule; (2) a poly(A) stretch is present in t-PA mRNA of both primary and secondary oocytes; (3) cleavage of this poly(A) stretch removes the nucleotides added to t-PA mRNA during meiotic maturation.

Finally, oocyte RNA was fractionated on poly(U)Sepharose (Fig. 10). t-PA mRNA from primary oocytes (GV), which has at most 40 As, was partially retained on the resin. In contrast, elongated t-PA mRNA from secondary oocytes $(\mathrm{OV})$ was entirely retained on the resin. Hence, the elongation of $t-P A$ mRNA during meiotic maturation is at least in part due to increased polyadenylation. Small amounts of a shorter hybridizing species were detected in secondary oocytes: this poly $(\mathrm{A})^{-} \mathrm{t}-\mathrm{PA}$ mRNA (Fig. 10), truncated near its 3' end (Fig. 9), may be a degradation intermediate.

\section{Discussion}

The presence of "maternal" mRNAs has been documented in many different species: These mRNAs accumulate during the growth phase of oocytes and are stored in a dormant, untranslated form until meiotic 


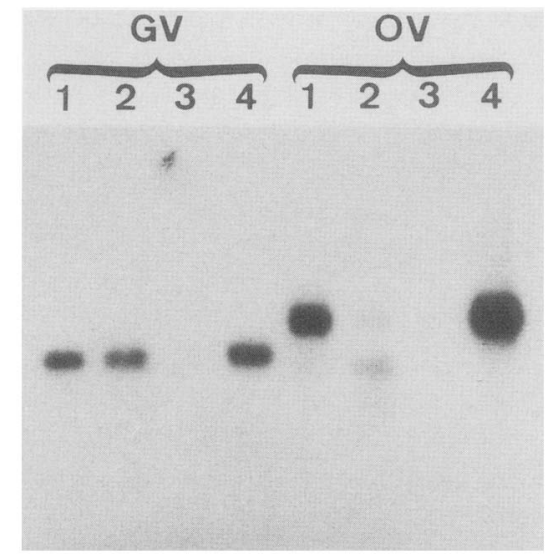

Figure 10. Poly $(\mathrm{U})$-Sepharose fractionation of $\mathrm{t}-\mathrm{PA}$ mRNA. (Lanes 1) Unfractionated RNA from 20 primary oocytes (GV) and 80 ovulated secondary oocytes (OV). RNAs from 80 primary oocytes $(\mathrm{GV})$ and from 320 ovulated secondary oocytes (OV) was adsorbed to poly(U)-Sepharose. (Lanes 2) Unbound RNA; (lanes 3) RNA eluted with $25 \%$ formamide; (lanes 4) RNA eluted with $90 \%$ formamide. Samples were analyzed by Northern blot hybridization using a probe transcribed from pSP65-MT . $_{\text {. }}$.

maturation or early embryogenesis, when they become recruited onto polysomes and translated (for review, see Davidson 1976; Bachvarova 1985). Although there is evidence for the existence of such mRNAs in mammalian oocytes (Cascio and Wassarman 1982), no specific example had as yet been identified. Taken together, the results presented here and earlier (Huarte et al. 1985) demonstrate the presence of dormant t-PA mRNA in the cytoplasm of fully grown primary mouse oocytes and its translational activation following resumption of meiosis, in the hours that precede ovulation. The insights that we have gained may also be relevant to other mammalian maternal mRNAs, as discussed below.

\section{Accumulation of t-PA $m R N A$ in the growing mouse oocyte}

The growth of primary mouse oocytes occurs over a period of approximately 2 weeks and results in an increase of 100-fold in volume and 20-fold in total RNA content (Bachvarova 1985). We have found that there is more t-PA mRNA in a single fully grown primary oocyte than in 500 primordial oocytes; it is thus clear that $t-P A$ mRNA concentration increases during oocyte growth. Total RNA and poly(A)-containing mRNA have been shown to accumulate in a quasilinear fashion throughout this growth phase until an oocyte diameter of $65 \mu \mathrm{m}$ is reached, with little increase thereafter (Sternlicht and Schultz 1981). The time course of the increase in t-PA mRNA content during oocyte growth indicates that the accumulation of this message is more abrupt (between the 40- and 50- $\mu \mathrm{m}$ stages) than that reported for total RNA. Therefore, individual mRNA species may accumulate at different times during the growth phase, with the gradual increase in total mRNA resulting from the integration of their asynchronous ac- cumulation. Whether the time of accumulation of a specific "maternal" mRNA reflects only the period during which the relevant gene is transcribed into a stable mRNA species, or whether there are discrete times at which individual mRNAs are selectively stabilized, is not yet known.

The t-PA mRNA level remained constant in fully grown primary oocytes cultured under conditions that prevent resumption of meiosis, even when transcription was blocked by actinomycin $\mathrm{D}$. Therefore, transcription of the t-PA gene is probably very low, and t-PA mRNA is stable in these cells, as has also been found for the bulk of endogenous oocyte RNA (Jahn et al. 1976; Bachvarova 1985) and for injected mRNAs (Ebert et al. 1984). Cell fractionation revealed that most of $\mathrm{t}-\mathrm{PA}$ mRNA is in the oocyte's cytoplasm; it follows that its dormancy and stability do not result from nuclear sequestration.

Although an abundance of about 10,000 molecules of t-PA mRNA per oocyte appears high by somatic cell standards, the primary mouse oocyte contains between 30 and $90 \mathrm{pg}$ of mRNA (Bachvarova 1985). Thus, t-PA mRNA represents less than $0.05 \%$ of total oocytic mRNA, and, as in somatic cells, it is not a high-abundance message. Interestingly, the electrophoretic mobilities of t-PA mRNAs from primary oocytes and from somatic cells were slightly different. Poly(A) tails were detected at the 3 'end of $\mathrm{t}$-PA mRNAs from both somatic cells and primary oocytes; however, the t-PA mRNA that accumulates in primary oocytes has undergone little polyadenylation (less than $40 \mathrm{As}$ ).

\section{Elongation of t-PA mRNA during meiotic maturation: Relationship to translational activation}

The synthesis of $\mathrm{t}-\mathrm{PA}$ is triggered upon resumption of meiosis, and enzyme can be detected $5 \mathrm{hr}$ after GVBD (Huarte et al. 1985). Starting within $3 \mathrm{hr}$ after GVBD, the apparent size of $\mathrm{t}$-PA mRNA increases progressively, to reach that of a molecule 400-600 nucleotides longer. This increase in size is due to a modification of the t-PA mRNA molecules present in the primary oocyte and not to de novo synthesis of a different species of $t$-PA mRNA, since it occurs also when transcription is prevented by actinomycin D or $\alpha$-amanitin. Furthermore, available evidence suggests that there is virtually no synthesis of new RNA after GVBD (Rodman and Bachvarova 1976; Bachvarova 1985), at a time when there is no visible nucleus and the chromosomes are completing the first meiotic division.

All t-PA mRNA molecules appeared to increase in size at a similar rate over the entire time period during which t-PA is synthesized (Huarte et al. 1985). Experiments using inhibitors of protein synthesis indicated that a translational event occurring around GVBD is required for the induction of t-PA mRNA elongation, whereas later on, translation, including that of t-PA mRNA itself, is not necessary for its progression. It is relevant to note that proteins required for the progression of maturing oocytes from metaphase I to metaphase II are also synthesized around the time of GVBD (Globus and Stein 1976; Schultz and Wassarman 1977). These re- 
sults imply that the primary oocyte contains at least two distinct classes of dormant mRNAs that will be translationally activated at, respectively, early and late times during meiotic maturation; $\mathrm{t}$-PA mRNA is a member of the second class.

The structural modification responsible for the size increase of t-PA mRNA has not been completely elucidated. However, this increase was abolished after treatment of secondary oocyte RNA by RNase $\mathrm{H}$ in the presence of oligo(dT). Thus, cleavage at a poly(A) stretch removes the nucleotides added during maturation. Poly $(U)$-Sepharose fractionation demonstrated an increase in the poly(A) content of t-PA mRNA during meiotic maturation. It remains to be determined whether the elongation is entirely due to a poly $(A)$ addition at the $3^{\prime}$ end of t-PA mRNA or whether some other modification occurs distally to a poly(A) stretch. In any event, this change is reminiscent of sequence-specific cytoplasmic polyadenylations of mRNAs that have been observed to occur during meiotic maturation or early embryogenesis in a variety of species, including Xenopus laevis (Colot and Rosbash 1982; Dworkin and DworkinRastl 1985), Spisula solidissima (Rosenthal et al. 1983; Rosenthal and Ruderman 1987), and Urechis caupo (Rosenthal and Wilt 1986). In mammals also, marked changes in total poly(A) content occur, e.g., decreases during meiotic maturation and increases after fertilization. Interestingly, actin mRNA is extensively deadenylated during meiotic maturation of mouse oocytes (Bachvarova et al. 1985), at the time when t-PA mRNA is polyadenylated. Thus, it appears that both deadenylation and adenylation reactions can occur concomitantly, which suggests that some kind of molecular discrimination must be operating.

The modification of t-PA mRNA is probably independent of its ongoing translation, since the mRNA elongation starts before there is detectable production of $\mathrm{t}$-PA. In addition, protein synthesis inhibitors added at $3 \mathrm{hr}$ post-GVBD block enzyme synthesis, but allow mRNA elongation. The deadenylation of actin mRNA during maturation referred to above is accompanied by a diminution in actin synthesis. Thus, for both proteins, synthesis is correlated with elongated, polyadenylated mRNAs. This would be similar to the situation described in Spisula (Rosenthal et al. 1983; Rosenthal and Ruderman 1987) and Xenopus (Colot and Rosbash 1982; Dworkin and Dworkin-Rastl 1985), where both adenylation and deadenylation of $\mathrm{mRNAs}$ occur during meiotic maturation and the presence of poly(A) stretch roughly correlates with translation. In agreement with this model, the translation efficiency of synthetic mRNAs injected into Xenopus laevis oocytes is grealy increased when the transcripts are polyadenylated (Drummond et al. 1985).

\section{Degradation of $t-P A m R N A$}

As pointed out above, $t$-PA mRNA in primary oocytes is very stable. In fact, the amount of this RNA per oocyte remains constant for the first $12 \mathrm{hr}$ of meiotic matura- tion, and only then begins to decrease. In mature secondary oocytes, the level is approximately $20 \%$ of that in primary oocytes, and $10 \mathrm{hr}$ after fertilization, t-PA mRNA has completely disappeared. Thus, this mRNA is accumulated in a dormant state, activated for translation, and then degraded. This time course is in accord with the general pattern of utilization of maternal components during early embryogenesis, in which use is followed by rapid destruction. The degradation of $t$-PA mRNA must be selective, since only half of the oocyte's poly $(\mathrm{A})^{+}$RNA is lost during maturation (DeLeon et al. 1983). It is possible that the structural change in t-PA mRNA that we have observed is related to its progressive lability, a point that may be experimentally approachable once the molecular mechanism of the change has been completely elucidated.

\section{Conclusions}

The identification of t-PA mRNA as a dormant mRNA in mouse oocytes raises the possibility of interesting further investigations into translational activation of maternal mRNAs. The most likely explanation of the structural change in t-PA mRNA is an elongation of its poly(A) tail. In several cases, two polyadenylating activities have been observed, one that acts immediately after transcription and a second that acts more slowly and elongates pre-existing poly(A) tails (Sawicki et al. 1977; Brawerman 1981; Moore and Sharp 1985). Such a twostage adenylation could explain our observations, with the first stage taking place in the growing primary oocyte and the second occurring only during maturation. More general is the question of how t-PA mRNA is selected for elongation and translation during maturation and whether elongation is a prerequisite for translation. The availability of the complete sequence of mouse t-PA mRNA (Rickles et al. 1988) and the injection of truncated or chimeric synthetic mRNAs into primary oocytes might allow the identification of sequences defining an mRNA as maternal.

Finally, although the experiments reported here do not further define the role of t-PA in oocyte physiology, they will be useful in exploring this question. As further information is obtained concerning the recruitment of $\mathrm{t}$-PA mRNA for translation, it may be possible to selectively inhibit expression of the enzyme during meiotic maturation. At that point, several of the possible roles of the protease, e.g., involvement in fertilization or participation in the zona reaction that blocks polyspermy, could be addressed directly.

\section{Methods}

Oocyte collection and culture

NMRI mice (Kleintierfarm Madoring, Basel) were used in these studies. Fully grown primary oocytes were collected as described (Huarte et al. 1985) and cultured in Biggers medium (Biggers et al. 1971; as modified by Paleos and Powers 1981). Mature secondary oocytes were obtained either from superovulated females or by in vitro maturation of primary oocytes 
(Huarte et al. 1985). Ovulated oocytes and fertilized eggs were collected in modified Whitten's medium (Hoppe and Pitts 1973). $\mathrm{Bt}_{2}$-cAMP, cycloheximide, puromycin, and actinomycin $D$ were purchased from Sigma, and $\alpha$-amanitin was from Calbiochem. Oocyte cultures were always in a humidified atmosphere of $5 \% \mathrm{CO}_{2}$ in air.

Two different methods for isolating growing oocytes were used. In the first (Eppig 1977), ovaries were placed in Brinster's medium (Brinster 1965) prepared without calcium, magnesium, or BSA but containing $0.25 \mathrm{~mm}$ sodium pyruvate; after removal of adhering connective and fatty tissues, they were transferred to the same medium containing $0.1 \%$ collagenase (Worthington) and $0.02 \%$ DNase I (Cooper Biomedical). Each ovary was torn into several pieces and incubated at $37^{\circ} \mathrm{C}$ for $45 \mathrm{~min}$; each piece was then punctured with fine needles, and the oocytes collected and washed from adhering somatic cells in complete Brinster's medium containing $3 \mathrm{mg} / \mathrm{ml}$ BSA. In the second method, the ovaries were placed in Hanks' balanced salt solution (HBSS), supplemented with $0.17 \%$ Pronase (Calbiochem), and torn into several pieces. After a 1- to 2-hr incubation at $37^{\circ} \mathrm{C}$, the follicles were pipetted up and down once with a micropipette of a diameter slightly less than the follicle diameter. The liberated oocytes were collected and transferred into drops of Biggers medium. The oocytes of $15 \mu \mathrm{m}$ in diameter were prepared by the method of Eppig (1977), but without the incubation with DNase I and collagenase, which proved unnecessary for ovaries derived from mice of 3 days of age. The oocytes of $40 \mu \mathrm{m}$ in diameter were prepared exactly according to Eppig. The oocytes of 50,60, and $65 \mu \mathrm{m}$ were prepared using the Pronase digestion.

\section{Biosynthetic labeling during meiotic maturation}

Fully grown primary oocytes, freshly isolated from ovaries and freed of follicular cells, were cultured for $16 \mathrm{hr}$ in the presence of $200 \mu \mathrm{Ci} / \mathrm{ml}\left[{ }^{35} \mathrm{~S}\right.$ ]cysteine (1370 Ci/mmole, Amersham). Half of the oocytes were cultured in the presence of $100 \mu \mathrm{g} / \mathrm{ml} \mathrm{Bt}_{2}$ cAMP to prevent resumption of meiosis. At the end of the culture, 120 secondary oocytes and 120 arrested primary oocytes were lysed in $50 \mu \mathrm{l}$ of NET-TS $(0.5 \mathrm{M} \mathrm{NaCl}, 0.001 \mathrm{M}$ EDTA, $0.05 \mathrm{M}$ Tris $\mathrm{HCl}(\mathrm{pH} 8.1), 1 \%$ Triton $\mathrm{X}-100,0.2 \% \mathrm{SDS})$ and subsequently divided into two aliquots. Immunoprecipitation with anti-human t-PA IgG and irrelevant IgG was preformed as previously described (Huarte et al. 1985). Supernatants and eluates of the $S$. aureus-bound immune complexes were subjected to SDS-PAGE ( $10 \%$ polyacrylamide). After drying, the gel was exposed to a Kodak XAR -5 film at $-80^{\circ} \mathrm{C}$ between intensifying screens.

\section{RNA extraction}

RNA was prepared by the method of Schibler et al. (1980), with some modifications. Oocytes or embryos were lysed in $100 \mu \mathrm{l}$ of $0.1 \mathrm{M}$ Tris- $\mathrm{HCl}(\mathrm{pH} \mathrm{7.4),} 1 \mathrm{M} \beta$-mercaptoethanol, and $4 \mathrm{M}$ gua: idium thiocyanate (Fluka, Switzerland). After addition of $10-30 \mu \mathrm{g}$ of carrier RNA, $8 \mu \mathrm{l}$ of $1 \mathrm{M}$ acetic acid, $5 \mu \mathrm{l}$ of $2 \mathrm{M}$ potassium acetate, and $60 \mu \mathrm{l}$ of ethanol, the nucleic acids were precipitated overnight at $-20^{\circ} \mathrm{C}$ and collected by centrifugation (15 min at $12,000 \mathrm{~g}$. The RNA was resuspended in $10 \mathrm{~mm}$ Tris$\mathrm{HCl}(\mathrm{pH} 8.1), 5 \mathrm{~mm}$ EDTA, and $0.1 \%$ SDS, extracted twice with phenol-chloroform, and ethanol-precipitated.

As multipurpose carrier, we used total RNA from bacteriophage T4-infected E. coli cultures (Belin et al. 1979) that had been subjected to a mild alkaline hydrolysis $\left(3 \mathrm{~min}\right.$ at $50^{\circ} \mathrm{C}$ in $50 \mathrm{mM} \mathrm{Na} \mathrm{CO}_{3}$ ) (Coffin and Billeter 1976). Phage infection results in a rapid loss of bacterial mRNAs and essentially elimi- nates unspecific hybridization of the probes to the carrier RNA in the samples; the mild hydrolysis ensures an homogeneous size distribution of the carrier in the Northern blots and allows the detection of any mRNAs, including those that would otherwise comigrate with the $23 \mathrm{~S}$ or $16 \mathrm{~S}$ rRNAs.

\section{Fractionation of primary oocytes : Preparation of germinal} vesicles and enucleated cytoplasms

Primary oocytes collected in Biggers medium containing 100 $\mu \mathrm{g} / \mathrm{ml} \mathrm{Bt}_{2}$-cAMP were first treated with acid Tyrode solution for 1-3 min to remove the zonae pellucidae (Hogan et al. 1986). The oocytes were then washed in Biggers medium containing 1 $\mathrm{mg} / \mathrm{ml}$ RNase-free BSA (Genofit), $100 \mu \mathrm{g} / \mathrm{ml} \mathrm{Bt}_{2}$-cAMP, $2 \mathrm{mM}$ DTT, and $1 \mathrm{U} / \mu \mathrm{l}$ RNasin (Genofit). After washing, groups of three oocytes were transferred to $3-\mu l$ drops of the same medium. The oocytes were broken with a narrow-bore, mouthoperated glass micropipette. The released germinal vesicles, which could be seen easily under the dissecting microscope by virtue of the refractile nucleoli, were washed by repeated pipetting, removed, and immediately lysed and processed as described for whole oocytes. The residual, partially dispersed cytoplasms together with the 3- $\mu$ l drops were then recovered and processed as described for whole oocytes.

\section{Treatment of RNA with RNase $H$}

RNase $\mathrm{H}$ treatment of total cellular RNA was done essentially as described (Schibler et al. 1980). RNAs (10 $\mu \mathrm{g}$ of carrier RNA/ sample) were mixed with $0.75 \mu \mathrm{g}$ of 24 -mer $\left(5^{\prime}\right.$-TTCTGCCCACAGCCGAGGCCCCAG; synthesized at the Unite d'Analyse Moléculaire of the Faculty of Medecine, Geneva) in the presence or in the absence of $0.5 \mu \mathrm{g}$ of oligo/dT) $)_{12-18}$ (Collaborative Research). After 2 min at $100^{\circ} \mathrm{C}$, the samples were chilled on ice, adjusted to $10 \mathrm{~mm}$ Tris- $\mathrm{HCl}(\mathrm{pH} 7.4), 130 \mathrm{~mm}$ ammonium chloride, $10 \mathrm{~mm}$ magnesium acetate, and $5 \%$ sucrose (final volume $15 \mu \mathrm{l}$ ), and digested with $1 \mathrm{U}$ of RNase $\mathrm{H}$ (Genofit) at $37^{\circ} \mathrm{C}$ for $20 \mathrm{~min}$. After the addition of $20 \mu \mathrm{l}$ of $1 \%$ SDS, $10 \mathrm{~mm}$ EDTA, and two extractions with phenol-chloroform, the nucleic acids were ethanol-precipitated and electrophoresed in a $1.6 \%$ agarose gel.

\section{$\operatorname{Poly}(U)-$ Sepharose fractionation}

Oocyte RNAs resuspended in $80 \mu \mathrm{l}$ of $0.7 \mathrm{M} \mathrm{NaCl}, 50 \mathrm{~mm}$ Tris$\mathrm{HCl}(\mathrm{pH} 7.4), 1 \%$ SDS, and 2 mM EDTA were added to $50 \mu \mathrm{l}$ of packed poly(U)-Sepharose (Pharmacia), resuspended, and washed extensively in the same buffer. After $20 \mathrm{~min}$ at $20^{\circ} \mathrm{C}$, the resin was centrifuged and washed once with $100 \mu \mathrm{l}$ of binding buffer; the unbound RNA was recovered by ethanol precipitation. After six additional washings with $1 \mathrm{ml}$ of binding buffer, the resin was incubated twice with $100 \mu \mathrm{l}$ of binding buffer supplemented with formamide ( $25 \%$ by volume); RNAs eluted at this step were recovered by ethanol precipitation with $20 \mu \mathrm{g}$ of carrier RNA. The poly $(\mathrm{A})^{+}$RNAs were then eluted from the resin by three successive incubations $(3 \mathrm{~min}$ at $37^{\circ} \mathrm{C}$ ) with $100 \mu \mathrm{l}$ of $90 \%$ formamide, $10 \mathrm{~mm}$ Tris- $\mathrm{HCl}(\mathrm{pH} 7.4)$, $2 \mathrm{mM}$ EDTA, and $0.2 \%$ SDS and recovered by ethanol precipitation with $50 \mu \mathrm{g}$ of carrier RNA.

\section{Plasmid constructions and in vitro transcription with SP6 RNA polymerase}

Three probes were prepared from the mouse t-PA cDNA clone pUC9-A33 (Rickles et al. 1988): (1) the 290-bp PstI-PvuII fragment (positions 1389-1679; Pennica et al. 1983) was subcloned 
between the SmaI and PstI sites of pSP65 (pSp65-MT 1$) ;(2)$ the 850-bp PvuI-PstI fragment (position 1680 to the $3^{\prime}$ end) was subcloned between the PstI and SmaI sites of pSP64 (pSP64$\left.\mathrm{MT}_{2}\right)_{;}(3)$ the GC and AT tails generated during cloning of the $\mathrm{t}$-PA cDNA were removed from pSP64-MT $\mathrm{MT}_{2}$ by cutting plasmid DNA at unique HindIII (in pSP64) and SpeI (located 100 bp before the end of the cDNA) sites, filling in with Klenow polymerase, and ligating (pSP64-MT 3 ). Another probe, specific for a different nonoverlapping region of mouse t-PA mRNA, was derived from a human $\mathrm{t}-\mathrm{PA}$ cDNA clone; the $614 \mathrm{bp}$ BgIII-EcoRI fragment (positions 188-801) isolated from pW349 $\mathrm{F}$, a plasmid containing a 2.6-kb t-PA cDNA insert (Fisher et al. 1985), was subcloned between the EcoRI and BamHI sites of pSP65 (pSP65HT). The human t-PA cDNA clone was provided by Dr. E.K. Waller (Rockefeller University, New York). Restriction enzymes were purchased from New England Biolabs and from Genofit. pSP65 and pSP64 (Melton et al. 1984) were from Genofit.

pSP65-MT 1, pSP64-MT 2, pSP64-MT ${ }_{3}$ or pSP65-HT, linearized respectively with PstI, EcoRI, EcoRI, or HindIII, were used as templates for bacteriophage SP6 RNA polymerase (Melton et al. 1984; Busso et al. 1986).

\section{Northern blot hybridization}

RNAs were denatured with glyoxal, electrophoresed in $1.2 \%$ agarose gels, and transferred overnight onto Byodine nylon membranes (Pall) according to Thomas (1980). Filters were baked $2 \mathrm{hr}$ at $80^{\circ} \mathrm{C}$ and boiled for $5 \mathrm{~min}$ in $20 \mathrm{~mm}$ Tris- $\mathrm{HCl} / \mathrm{pH}$ 8.1) to remove residual glyoxal. Filters were prehybridized for at least $3 \mathrm{hr}$ at $58^{\circ} \mathrm{C}$ with $200 \mu \mathrm{l} / \mathrm{cm}^{2}$ of hybridization mixture (Busso et al. 1986), then hybridized at the same temperature for $15-20 \mathrm{hr}$ in fresh hybridization mixture $\left(50 \mu \mathrm{l} / \mathrm{cm}^{2}\right)$ containing $5 \mathrm{ng} / \mathrm{ml}$ of ${ }^{32} \mathrm{P}$-labeled cRNA probe. Filters were washed twice at $58^{\circ} \mathrm{C}$ with $3 \times$ SSC, $2 \times$ Denhardt's solution, and three times at $75^{\circ} \mathrm{C}$ with $0.2 \times$ SSC, $0.1 \%$ SDS, and $0.1 \%$ Na-pyrophosphate. Filters were exposed to Kodak XAR- 5 film at $-80^{\circ} \mathrm{C}$ between intensifying screens.

\section{Acknowledgments}

We thank R.J. Rickles for providing the mouse t-PA cDNA clone pUC9-A33 and its sequence, D. Kolakofsky for the synthetic oligonucleotide, P. Gubler and C. Combépine for technical assistance, and N. Gerber and E. Denkinger for photographic work. This work was supported by grants from the Swiss National Science Foundation (3.075-0.84) and the Sandoz Stiftung zur Förderung der medizinisch-biologischen Wissenschaften. S.S. was the recipient of an American Cancer Society Scholar Grant (SG-145).

\section{References}

Bachvarova, R. 1985. Gene expression during oogenesis and oocyte development in the mammal. In Developmental biology: A comprehensive synthesis, vol. 1: Oogenesis (ed. L.W. Browder), pp. 453-524, Plenum, New York.

Bachvarova, R., V. DeLeon, A. Johnson, G. Kaplan, and B.V. Paynton. 1985. Changes in total RNA, polyadenylated RNA, and actin mRNA during meiotic maturation of mouse oocytes. Dev. Biol. 108: 325-331.

Belin, D., J. Hedgpeth, G.B. Selzer, and R.H. Epstein. 1979. Temperature-sensitive mutation in the initiation codon of the rIIB gene of bacteriophage T4. Proc. Natl. Acad. Sci. 76: 700-704.

Biggers, J.D., W.K. Whitten, and D.G. Whittingham. 1971. The culture of mouse embryos in vitro. In Methods in mammalian embryology (ed. G.C. Daniel), pp. 86-116, San Francisco.

Braude, P., H. Pelham, G. Flach, and R. Lobatto. 1979. Posttranscriptional control in the early mouse embryo. Nature 282: 102-105.

Brawerman, G. 1981. The role of the poly(A) sequence in mammalian messenger RNA. CRC Crit. Rev. Biochem. 10: 1-38.

Brinster, R.L. 1965. Studies on the development of mouse embryos in vitro II. The effect of energy source. I. Exp. Zool. 158: $59-68$.

Busso, N., D. Belin, C. Failly-Crépin, and J.-D. Vassalli. 1986. Plasminogen activators and their inhibitors in a human mammary cell line (HBL-100): Modulation by glucocorticoids. J. Biol. Chem. 261: 9309-9315.

Cascio, S.M., and P.M. Wassarman. 1982. Program of early development in the mammal: Post-transcriptional control of a class of proteins synthesized by mouse oocytes and early embryos. Dev. Biol. 89: 397-408.

Coffin, J.M., and M.A. Billeter. 1976. A physical map of the Rous sarcoma virus genome. J. Mol. Biol. 100: 293-318.

Colot, H.V., and M. Rosbash. 1982. Behavior of individual maternal poly $(\mathrm{A})^{+}$RNAs during embryogenesis of Xenopus laevis. Dev. Biol. 94: 79-86.

Davidson, E.H. 1976. Gene activity in early development. Academic Press, New York.

DeLeon, V., A. Johnson, and R. Bachvarova. 1983. Half-lives and relative amounts of stored and polysomal ribosomes and poly $(\mathrm{A})^{+}$RNA in mouse oocytes. Dev. Biol. 98: 400-408.

Drummond, D.R., J. Armstrong, and A. Colman. 1985. The effect of capping and polyadenylation on the stability, movement and translation of synthetic messenger RNAs in Xenopus oocytes. Nucleic Acids Res. 13: 7375-7394.

Dworkin, M.B., and E. Dworkin-Rastl. 1985. Changes in RNA titers and polyadenylation during oogenesis and oocyte maturation in Xenopus laevis. Dev. Biol. 112: 451-457.

Ebert, K.M., B.V. Paynton, G.S. McKnight, and R.L. Brinster 1984. Translations and stability of ovalbumin messenger RNA injected into growing oocytes and fertilized ova of mice. J. Embryol. Exp. Morphol. 84: 91-103.

Eppig, J.J. 1977. Analysis of mouse oogenesis in vitro: Oocyte isolation and the utilization of exogenous energy sources by growing oocytes. J. Exp. Zool. 198: 375-382.

Fisher, R., E.K. Waller, G. Grossi, D. Thompson, R. Tizard, and W.-D. Schleuning. 1985. Isolation and characterization of the human tissue-type plasminogen activator structural gene including its 5' flanking region. I. Biol. Chem. 260: $11223-11230$.

Globus, M.S. and M.P. Stein. 1976. Qualitative patterns of protein synthesis in the mouse oocyte. I. Exp. Zool. 198: 337342.

Hogan, B., F. Costantini, and E. Lacy. 1986. Manipulating the mouse embryo: A laboratory manual. Cold Spring Harbor Laboratory, Cold Spring Harbor, New York.

Hoppe, P.C. and S. Pitts. 1973. Fertilization in vitro and development of mouse ova. Biol. Reprod. 8: 420-426.

Huarte, J., D. Belin, and J.-D. Vassalli. 1985. Plasminogen activator in mouse and rat oocytes: Induction during meiotic maturation. Cell 43: 551-558.

Jahn, C.L., M.M. Baran, and R. Bachvarova. 1976. Stability of RNA synthesized by the mouse oocyte during its major growth phase. J. Exp. Zool. 197: 161-172.

Marotti, K.R., D. Belin, and S. Strickland. 1982. The production of distinct forms of plasminogen activator by mouse embryonic cells. Dev. Biol. 90: 154-159.

Melton, D.A., P.A. Krieg, M.R. Rebagliati, T. Maniatis, K. Zinn, 
and M.R. Green. 1984. Efficient in vitro synthesis of biologically active RNA and RNA hybridization probes from plasmids containing a bacteriophage SP6 promoter. Nucleic Acids Res. 12: 7035-7056.

Moore, C.L. and P.A. Sharp. 1985. Accurate cleavage and polyadenylation of exogenous RNA substrate. Cell 41: 845-855.

Paleos, G.A., and R.D. Powers 1981. The effect of calcium on the first meiotic division of the mammalian oocyte. I. Exp. Zool. 217: 409-416.

Pennica, D., W.E. Holmes, W.J. Kohr, R.N. Harkins, G.A. Vehar, C.A. Ward, W.F. Bennett, E. Yelverton, P.H. Seeburg, H.L. Heyneker, D.V. Goeddel, and D. Collen. 1983. Cloning and expression of human tissue-type plasminogen activator cDNA in E. coli. Nature 301: 214-221.

Rickles, R.J., A.L. Darrow, and S. Strickland. 1988. Molecular cloning of complementary DNA to mouse tissue plasminogen activator mRNA and its expression during F9 teratocarcinoma cell differentiation. J. Biol. Chem. (in press).

Rodman, T.C., and R. Bachvarova. 1976. RNA synthesis in preovulatory mouse oocytes. J. Cell Biol. 70: 251-257.

Rosenthal, E.T. and J.V. Ruderman. 1987. Widespread changes in the translation and adenylation of maternal messenger RNAs following fertilization of Spisula oocytes. Dev. Biol. 121: 237-246.

Rosenthal, E.T. and F.H. Wilt. 1986. Patterns of maternal RNA accumulation and adenylation during oogenesis in Urechis caupo. Dev. Biol. 117: 55-63.

Rosenthal, E.T., T.R. Tansey, and J.V. Ruderman. 1983. Sequence specific adenylations and deadenylations accompany changes in the translation of maternal messenger RNA after fertilization of Spisula oocytes. J. Mol. Biol. 166: 309-327.

Sawicki, S.G., W. Jelinek, and J.E. Darnell. 1977. 3'-terminal addition to HeLa cell nuclear and cytoplasmic poly(A). $I$. Mol. Biol. 113: 219-224.

Schibler, U., M. Tosi, A.-C. Pittet, L. Fabiani, and P.K. Wellauer. 1980. Tissue-specific expression of mouse $\alpha$-amylase genes. J. Mol. Biol. 142: 93-116.

Schultz, R.M. and P.M. Wassarman. 1977. Biochemical studies of mammalian oogenesis: Protein synthesis during oocyte growth and meiotic maturation in the mouse. J. Cell Sci. 24: $167-194$.

Sternlicht, A.L. and R.M. Schultz. 1981. Biochemical studies of mammalian oogenesis: Kinetics of accumulation of total and poly(A)-containing RNA during growth of the mouse oocyte. J. Exp. Zool. 215: 191-200.

Thomas, P.S. 1980. Hybridization of denatured RNA and small DNA fragments transferred to nitrocellulose. Proc. Natl. Acad. Sci. 77: 5201-5205.

Vournakis, J.N., A. Efstratiadis, and F.C. Kafatos. 1975. Electrophoretic patterns of deadenylated chorion and globin mRNAs. Proc. Natl. Acad. Sci. 72: 2959-2963.

Wassarman, P.M. 1983. Oogenesis: Synthetic events in the developing mammalian egg. In Mechanism and control of animal fertilization (ed. J.F. Hartman), pp. 1-54, Academic Press, New York.

Wassarman, P.M., R.M. Schultz, G.E. Letourneau, M.J. LaMarca, W.J. Josefowicz, and J.D. Bleil. 1979. Meiotic maturation of mouse oocytes in vitro. In Ovarian follicular and corpus luteum function (ed. Channing and Marsh), pp. 251-268. 


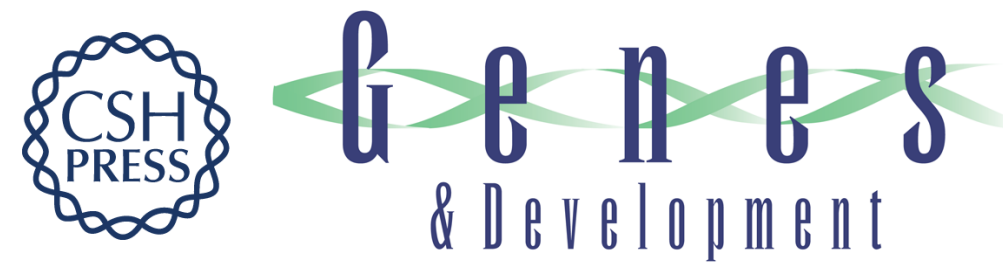

\section{Meiotic maturation of mouse oocytes triggers the translation and polyadenylation of dormant tissue-type plasminogen activator mRNA.}

J Huarte, D Belin, A Vassalli, et al.

Genes Dev. 1987, 1:

Access the most recent version at doi:10.1101/gad.1.10.1201

References

This article cites 34 articles, 7 of which can be accessed free at:

http://genesdev.cshlp.org/content/1/10/1201.full.html\#ref-list-1

License

Email Alerting

Receive free email alerts when new articles cite this article - sign up in the box at the top Service right corner of the article or click here.

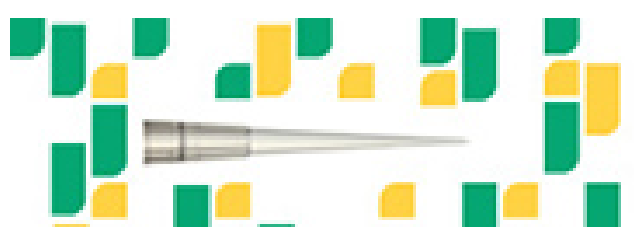

Focused on your science. 